\title{
Reproductive Studies in Ipecac (Cephaelis ipecacuanha (Brot.) A. Rich; Rubiaceae): Flower Bud and Anther Size Associated to Male Gamete Development Stages
}

\author{
Margarete Magalhães de Souza ${ }^{1, *}$, Ernane Ronie Martins ${ }^{2}$, \\ Telma Nair Santana Pereira ${ }^{1}$ and \\ Luiz Orlando de Oliveira ${ }^{3}$
${ }^{1}$ Universidade Estadual do Norte Fluminense (UENF), Centro de Ciências e Tecnologias Agropecuárias, Laboratório de Melhoramento Genético Vegetal, Av. Alberto Lamego 2000, Campos dos Goytacazes, 28013-600, RJ, Brasil
${ }^{2}$ Universidade Federal de Minas Gerais (UFMG), Núcleo de Ciências Agrárias, Caixa Postal 135, Montes Claros, MG, 39404-006, Brasil
${ }^{3}$ Universidade Federal de Viçosa (UFV), Centro de Ciências Biológicas, Departamento de Bioquímica \\ e Biologia Molecular, Av. P.H. Rolfs, s/n, Viçosa, MG, 36571-000, Brasil
}

Received May 27, 2003; accepted October 3, 2003

\begin{abstract}
Summary Reproductive studies were carried out on Brazilian accessions of Cephaelis ipecacuan$h a$, which is considered a threatened species. Meiotic behavior was studied using squashing technique with $1 \%$ acetic carmine and floral buds and anther were measured for the following male gamete development stages: meiosis I, meiosis II, tetrads, microspores and pollen. Bud and anther length showed significant differences $(\mathrm{P}<0.01)$ among the stages of pollen development. There was high significant correlation between bud and anther length by Pearson correlation. Tukey test results indicated that each analyzed stage could be associated to bud length mean but it was not found the same association for anther length.
\end{abstract}

Key words Cephaelis ipecacunha, Poaia, Microsporogenesis, Microgametogenesis, Flower bud and anther size.

Ipeca, poaia or ipecacuanha ( $n=11$; Assis 1992) is the term used in Brazil to designate the medicinal species Cephaelis ipecacuanha, known as ipecac in English language countries and raicilla in Central America countries (Torres 1972). Its center of origin is located in American continent. Native populations are restricted to three regions: Central America, Southwest of the Brazilian Amazon region (Mato Grosso and Rondonia States) and Atlantic forest, principally in Minas Gerais, Espírito Santo, Rio de Janeiro and Bahia States (Assis 1992).

According to Akerele et al. (1991), ipecac was considered one of the more important medicinal plants of the world. The more remarkable medicinal characteristics are found in the roots with its flavor bitter taste and nauseating smell (Gattoni 1960, Oliveira and Martins 1998). The main composts responsible for its therapeutic applications are the alkaloids emetine, cephaeline and psycothrine (Sousa et al. 1991). Brazilian ipecac is considered the most valuable because it shows highest emetine content (Assis 1992). These composites are effective to provoke vomits (Sousa et al. 1991), act as expectorant and treat against amoeba Entamoeba hystolitica (Bruneton 1995), among other applications (Trease and Evans 1989, Sousa et al. 1991, Carrinconde et al. 1995).

Ipecac is considered a threatened species as others Brazilian native species that are disappearing due to diminution of their habitats in natural vegetation areas (Oliveira and Martins 1998, Costa

* Corresponding author, e-mail: souzamag@ig.com.br 
et al. 2000). Many wild species have suffered narrowing of their genetic base due to predatory collection or vegetation cover destruction (McKeown 1996), and this fact can lead them to be endangered by natural selection action (Brown 1988). On this bases, the aim of this study was to document and report information on identification of flower bud and anther size associated to main stages of male gamete development to help providing a better understanding of reproductive aspects in this species in despite of its considerable medicinal importance, in order to give support to preservation and breeding strategy.

\section{Material and methods}

We analyzed C. ipecacuanha accessions from Brazil, collected in Caratinga and Carangolas (Mato Grosso), and Itaperuna (Rio de Janeiro) cities. The species were kept in pots in a greenhouse at the Research Support Unit at UENF.

For meiotic studies, flower buds were fixed in ethanol-acetic acid $(3: 1)$ at room temperature for $24 \mathrm{~h}$, transferred to $70 \%$ alcohol and stored under refrigeration until use. Temporary slides were prepared by the squashing technique and the cells were stained with $1 \%$ acetic carmine. Before squashing, buds and anthers were measured and the values were associated to microsporogenesis and microgametogenesis stages. Date was submitted to analysis of variance (ANOVA), means were tested by the procedure of Tukey at $5 \%$ probability and Pearson correlation was performed between bud and anther sizes. Statistical analysis was performed considering a randomized experimental design by the program Genes (Cruz 2001).

\section{Results}

Mean values of flower bud and anther are shown on Table 1. Bud and anther length showed significant differences $(\mathrm{P}<0.01)$ among the stages of male gamete development by $\mathrm{F}$ test (Table 2), and microsporogenesis (Fig. 1a-e) and microgametogenesis (Fig. 1f) were associated to flower bud and anther length (Fig. 2). Meiosis I and II stages could not be differentiated in relation to anther length due to asynchronism into the same anther in relation to the division phases: anthers showing the same size displayed different meiotic phases; therefore, values found for one stage overlapped the values found for other one.

For studies in ipecac involving microspore (uninucleate, haploid cell) in vitro culture, it is rather indicated to use flower buds length from $1.8 \mathrm{~mm}$ and anther from $0.9 \mathrm{~mm}$. For obtaining pollen grains, that is binucleate after its liberation from anther, it is indicated collecting from $2.5 \mathrm{~mm}$ for flower bud length and from 1.2 for anther. In relation to meiosis I, flower buds between 0.9-1.4 mm length, and to meiosis II, 1.5-1.6 mm length may be collected. For both meiosis I and II, anther length may be estimated between $0.5-0.7 \mathrm{~mm}$.

Table 1. Pollen development stages associated to minimum, maximum and mean values of flower bud and anther length ( $\mathrm{mm})$ in Cephaelis ipecacuanha

\begin{tabular}{|c|c|c|c|c|c|c|}
\hline \multirow{2}{*}{ Stages } & \multicolumn{3}{|c|}{ Bud size } & \multicolumn{3}{|c|}{ Anther size } \\
\hline & Values & Mean $( \pm \mathrm{sd})$ & C.V. $(\%)$ & Values & Mean $( \pm \mathrm{sd})$ & C.V. (\%) \\
\hline Meiosis I & $0.9-1.5$ & $1.18 \pm 0.17$ & 14.54 & $0.5-0.7$ & $0.56 \pm 0.07$ & 13.23 \\
\hline Meiosis II & $1.5-1.8$ & $1.58 \pm 0.11$ & 7.09 & $0.5-0.7$ & $0.62 \pm 0.07$ & 11.31 \\
\hline Tetrad & $1.6-2.0$ & $1.83 \pm 0.13$ & 7.08 & $0.7-0.8$ & $0.75 \pm 0.05$ & 7.12 \\
\hline Microspore & $1.8-2.4$ & $2.12 \pm 0.23$ & 11.17 & $0.7-1.2$ & $0.93 \pm 0.19$ & 20.50 \\
\hline Pollen grain & $2.5-2.7$ & $2.58 \pm 0.06$ & 2.47 & $1.2-1.6$ & $1.35 \pm 0.13$ & 9.69 \\
\hline
\end{tabular}

$\mathrm{sd}=$ standard deviation; $\mathrm{C} . \mathrm{V} .=$ coefficient of variation . 
Table 2. ANOVA summary for the characteristics bud length and anther length in relation to stages of male gamete development in Cephaelis ipecacuanha

\begin{tabular}{|c|c|c|c|}
\hline \multirow{2}{*}{ Source of variation } & \multirow{2}{*}{$\mathrm{DF}$} & \multicolumn{2}{|c|}{ Mean squares } \\
\hline & & Bud length & Anther length \\
\hline Stages & 4 & $2.25275^{*} *$ & $0.801625^{* *}$ \\
\hline Error & 35 & 0.024 & 0.135 \\
\hline $\mathrm{CV}$ & & $8.30 \%$ & $13.75 \%$ \\
\hline
\end{tabular}

** Significance at the $1 \%(\mathrm{P}<0.01)$ probability level by $\mathrm{F}$ test, $\mathrm{CV}$ : Coefficient of variation, DF: Degree of freedom * The results are means of eight repetitions.
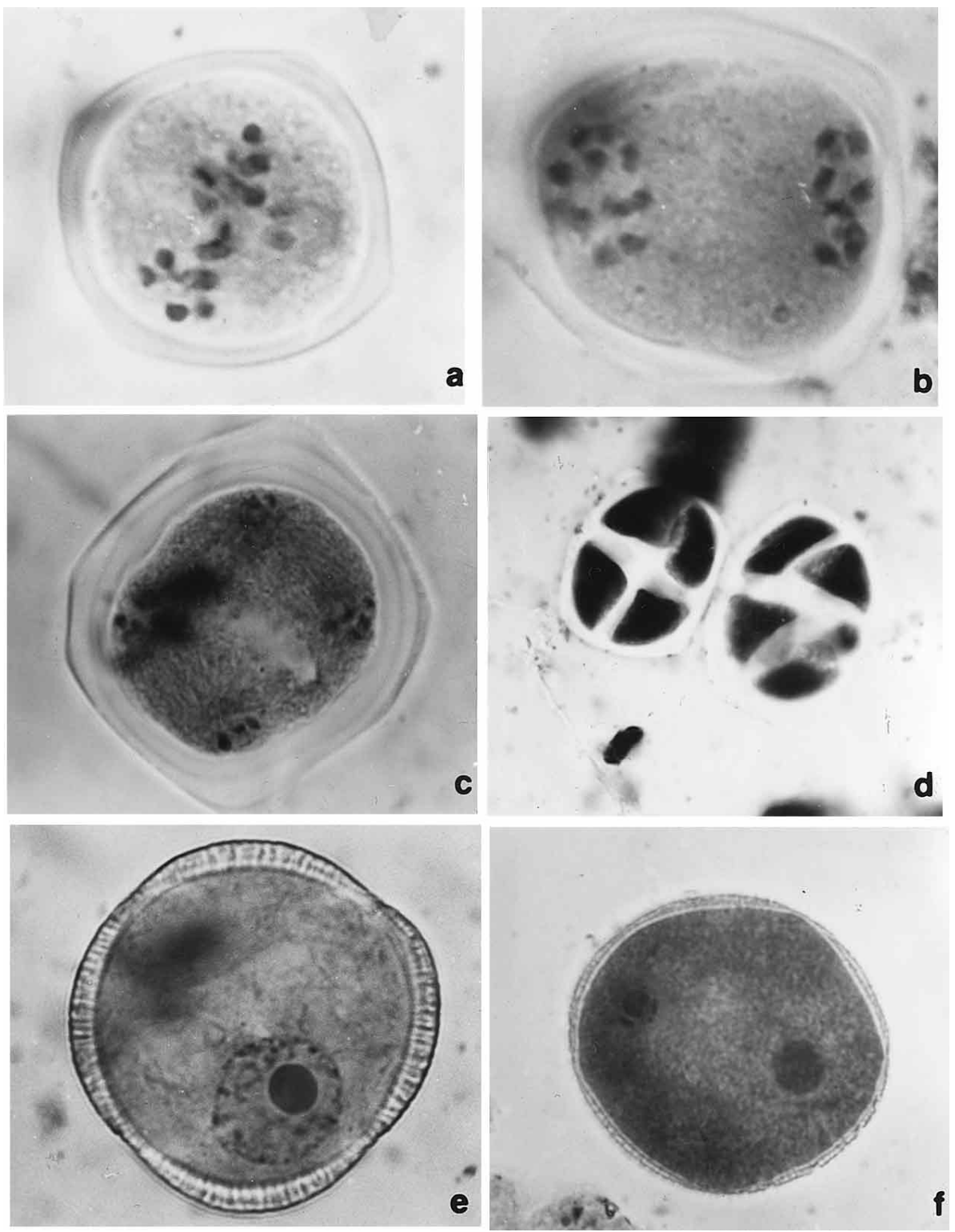

Fig. 1. Microsporogenesis and microgametogenesis in Cephaelis ipecacuanha. a) Metaphase I, b) Early telophase I, c) Telophase II, d) Tetrads, e) Late microspore, f) Binucleate pollen. 
Table 3. Pearson correlation between the variables bud length and anther length in Cephaelis ipecacuanha

\begin{tabular}{ccccc}
\hline \hline \multirow{2}{*}{ Variables } & Cov $(\mathrm{X}, \mathrm{Y})$ & Observations & Correlation & $\alpha(\%)$ \\
\hline Bud length $\times$ anther length & 1.1201 & 80 & 0.3753 & $0.0719^{* *}$ \\
\hline
\end{tabular}

** Significance at the $1 \%$ probability level.

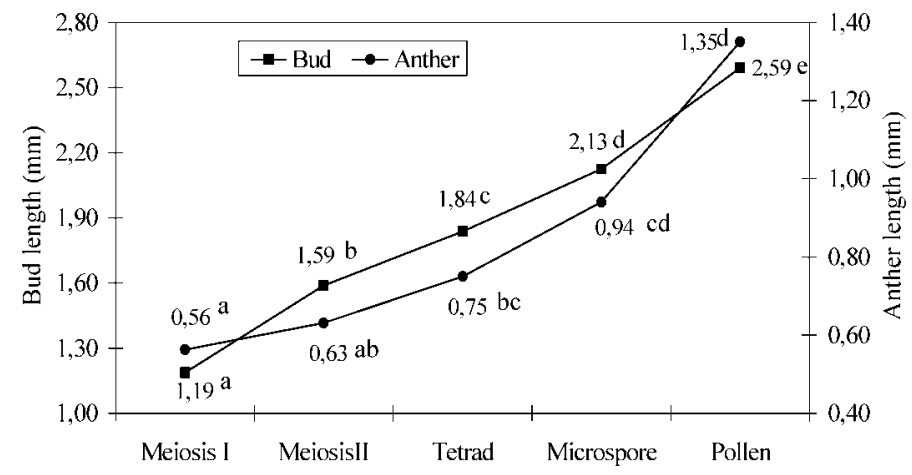

Fig. 2. Mean values of bud and anther length in function of male gamete development stages in Cephaelis ipecacuanha. Means followed by the same letter in the same line do not differ by the Tukey test at $5 \%$ probability.

Means of bud length were grouped in five levels (Fig. 2a-e) while for length anther it was observed four levels (Fig. 2a-d) by Tukey test, indicating that each analyzed stage could be associated to bud length mean but it was not found the same association for anther length, that is indicates only to differentiation between the microgametogenesis stages. There was high significant correlation between bud and anther length by Pearson correlation (Table 3).

\section{Discussion}

Pollen development in higher plants is a cooperative process requiring multiple interactions between the sporophytic plant and the developing male gametophyte (Chaubal et al. 2000). Anther development can be divided into 10 stages. They are based primarily on the state of the male cells and the tapetum, and the surrounding anther wall tissues: 1) mass stages; 2) meiocyte stage; 3) dyad stage; 4) tetrad stage; 5) early microspore stage; 6) midmicrospore stage; 7) late microspore stage (uninucleate); 8) early pollen stage (binucleate); 9) midpollen stage; 10) late pollen stage (bi or trinucleate), so that stages 2-7 represent microsporogenesis and stages 8-10 represent microgametogenesis (Horner and Palmer 1995, Palmer and Horner 2000).

Due to embryos arising from vegetative cell, generative cell, or symmetrical mitotic division of haploid microspore, many authors try for monitoring the meiotic division process to associate the flower bud size to different meiotic phases or to pollen development stages. Souza et al. (2002) could associate only the microgmetogenesis stages to anther and bud length in yellow passion fruit. Andrade et al. (1996) made cytological analysis in four coffee cultivars (Coffea arabica L.), and in all the genotypes flower bud and anther size were associated only to microspore development stages.

Other characteristics beyond flower bud size could be associated to microgametogenesis stages. Lauxen et al. (1995) related microsporogenesis stages to four pre-established intervals of 
flower bud length in three Brazilian cultivars of soybean (Glycine max (L.) Merrill), and observed the lack of synchronism among anthers from the same flower bud in relation to meiosis I and II. In sweet pepper (Capsicum annum L.), the morphological characteristics could be associated to microspore stages in all the genotypes that showed flower buds with the same-sized petals or petals a little larger than sepals, and anthers with anthocyanin traces in its extremity (Silva et al. 1995). Luz et al. (2000) collected sweet pepper bud flowers when the petals were about the same size of sepals, which correspond to anthers containing unvacuolated microspores, with a central nucleus. Willcox et al. (1990), studying peanut (Arachis hypogaea L.), observed that not the size but the flower bud shape might be correlated with the microspore development, even though this difference could occur due to environmental conditions and not only as a result of genotype differences.

That type of information is important for the success of research that involves anther culture technique, and the non-acquaintance in relation to the flower development period that the microsporogenesis and microgmetogenesis stages are occurring is an obstacle. Anthers that show from tetrads to binucleate pollen stages are the best to the in vitro culture, but for most species, it is necessary the manipulation of the uninucleate, gametic cell (Zhang and Lespinasse 1992). According to Mascarenhas (1990), rRNA genes of pollen grains seem to be switched off $24 \mathrm{~h}$ after the first mitosis being impossible to revert the cell development to form a plant and not a pollen grain.

Micropropagation has been a tool to rescue endangered plants (Moura-Costa et al. 1993, Palomino et al. 1999). In C. ipecacuanha callus culture were performed to produce alkaloids (Teshima et al. 1988), and studies in vitro to obtain the whole plants was successful (Jha and Jha 1989, Ideda et al. 1989). Costa et al. (2000) obtained an excellent emetine production using twelveyear-old plants from tissue culture. As observed in this study, the flower bud size might be used as an indicator to main stages of pollen grain development, while the same association does not occur in many other species (Willcox et al. 1990, Souza et al. 2002). These stages of development of gamete at the time of culture has been shown to be an important factor in the production of haploids via anther culture (Maheshwari et al. 1980), which could be an interesting option regarding future breeding programs involving $C$. ipecacuanha, for achieving homozygosity in relation to composites production once the alkaloid contents range among plants (Cruz 1935, Addor 1945). Making feasible the in vitro propagation of ipecac could be an important strategy to obtain clones that show high yield beyond constancy in the production and accumulation of alkaloids (Oliveira and Martins 1998).

\section{References}

Addor, A. A. 1945. Considerações acerca da poaia. Bol. Minist. Agric. 34: 1-18.

Akerele, O., Heywood, V. and Synge, H. 1991. The Conservation of Medicinal Plants. Cambrige University Press, Cambrige.

Andrade, L. M. C. O., Davide, L. C. and Pasqual, M. 1996. Relação entre a microsporogênese e o tamanho do botão floral e de anteras em café (Coffea arabica L.). Rev. Bras. Genet. 42: 138.

Assis, M. C. 1992. Aspectos taxonômicos, anatômicos e econômicos da "ipeca" Psychotria ipecacuanha (Brot.) Stokes (RUBIACEAE). Dissertação de Mestrado, Universidade de São Paulo.

Brown, K. S. 1988. Engenharia ecológica: novas perspectivas de seleção e manejo de plantas medicinais. Acta Amazon. 18: 291-303.

Bruneton, J. 1995. Pharmacognosy, Phytochemistry, Medicinal Plants. Lavoisier, Paris.

Carrinconde, C., Moraes, D. and Fritschen, M. von. 1995. Plantas Medicinais e Plantas Alimenticias. Centro Nordestino de Medicina Popular, Olinda.

Chaubal, R., Zanella, C., Trimnel, M. R., Fox, T. W., Albertsen, M. C. and Bedinger, P. 2000. Two male-sterile mutants of Zea mays (Poaceae) with an extra cell division in the anther wall. Amer. J. Bot. 87: 1193-1201.

Costa, M. P., Pinto, J. E. B. P., França, S. C., Lameira, O. A., Conceição, H. O. and Santiago, E. J. A. 2000. Crescimento e teor de emetina em plantas de ipeca (Cephaelis ipecacuanha A. Richard.) obtidas in vitro e submetidas às condições de soluções nutritivas em casa-de-vegetação. Ciênc. Agrotec. 24: 46-53.

Cruz, C. D. 2001. Programa Genes (Versão Windows), Aplicativo Computacional em Genética e Estatística. Imprensa Uni- 
versitária UFV, Viçosa.

Cruz, G. P. G. 1935. Ipecacuanha. Rev. Fl. Med. 1: 135.

Gattoni, L. A. 1960. A raiz de ipecacuanha. A Fazenda 55: 16-18.

Horner, H. T. and Palmer, R. G. 1995. Mechanisms of genic male sterility. Crop Sci. 35: 1527-1535.

Ideda, K., Teshima, D., Aoyamata, T., Satake, M. and Shimomura, K. 1989. Clonal propagation of Cephaelis ipecacuanha. Plant Cell Rep. 7: 288-291.

Jha, S. and Jha, T. 1989. Micropropagation of Cephaelis ipecacuanha A. Rich. Plant Cell Rep. 8: 437-439.

Lauxen, M. S., Kaltchuk-Santos, E. and Bodanese-Zanettini, M. H. 1995. Relação entre tamanho de botão floral e o estádio de desenvolvimento do grão de pólen em soja (Glycine Max (L.) Merr.). Rev. Bras. Genet. 41 (Suplemento): 419.

Luz, J. M. Q., Pinto, J. E. B. P. and Pereira, I. A. M. 2000. Caracterização histológica da indução embriogênica em anteras de pimentão. Ciênc. Agrotec. 24: 17-21.

Maheshwari, S. C., Tyagi, A. K., Malhotra, K. and Sopory, S. K. 1980. Induction of haploidy from pollen grains in angiosperms - the current status. Theor. Appl. Genet. 58: 193-206.

Mascarenhas, J. P. 1990. Gene activity during pollen development. Annu. Rev. Plant Physiol. Plant Mol. Biol. 41: $317-338$.

McKeown, K. 1996. Germplasm conservation on neotropical medicinal plants and a workshop on Fila Chonta in Costa Rica. Acta Hortic., No. 426.

Moura-Costa, P. H., Viana, A. M. and Mantel, S. H. 1993. In vitro plantlet regeneration of Ocotea catharinensis and endangered Brazilian hardwood forest tree. Plant Cell Tissue Organ Cult. 35: 279-286.

Oliveira, L. O. and Martins, E. R. 1998. O desafio das plantas medicinais brasileiras. I-O caso da poaia (Cephaelis ipecacuanha). UENF, Campos dos Goytacazes.

Palmer, R. G. and Horner, H. T. 2000. Genetics and cytology of a genic male-sterile, female-sterile mutant from a transposon-containing soybean population. J. Hered. 91: 378-383.

Palomino, G., Dolezel, J., Cid, R., Brunner, I., Méndez, I. and Rubluo, A. 1999. Nuclear genome stability of Mammillaria san-angelensis (Cactaceae) regenerants induced by auxins in long-term in vitro culture. Plant Sci. 141: 191-200.

Silva, R., Luz, J. M. Q., Davide, L. C. and Pinto, J. E. B. P. 1995. Relação entre microsporogênese e tamanho do botão floral em pimentão (Capsicum annum L.). Rev. Bras. Genet. 41: 433.

Sousa, M. P., Matos, M. E. O., Matos, F. J. A., Machado, M. I. L. and Craveiro, A. A. 1991. Constituintes químicos ativos de plantas medicinais brasileiras. EUFC, Fortaleza.

Souza, M. M., Pereira, T. N. S. and Martins, E. R. 2002. Microsporogênese e microgametogênese associadas ao tamanho do botão floral e da antera, e viabilidade polínica em maracujazeiro-amarelo (Passiflora edulis Sims f. flavicarpa Degener). Ciênc. Agrotec. 26: 1209-1217.

Teshima, D., Ikeda, K., Satake, M., Aoyamata, T. and Shimomura, K. 1988. Production of emetic alkaloid by in vitro culture of Cephaelis ipecacuanha A. Rich. Plant Cell Rep. 7: 278-280.

Torres, L. A. C. 1972. Contribuicion al conocimiento de la Cephaelis ipecacuanha (Brot.) A. Rich., com especial referencia a Colombia. In: Simposio Internacional sobre plantas de interesse economico de la flora Amazônica-IICAtrópicos. Informes de conferências, cursos y reuniones, $\mathrm{n}^{\circ}$ 93. Costa Rica.

Trease, G. E. and Evans, W. C. 1989. Pharmacognosy. Bailliére Tindal, London.

Willcox, M. C., Reed, S. M., Burns, J. A. and Wynne, J. C. 1990. Microsporogenesis in peanut (Arachis hypogaea). Amer. J. Bot. 77: 1257-1259.

Zhang, Y. X. and Lespinasse, Y. 1992. Haploids. In: Hammerschlag, F. A. and Litz, R. E (eds.). Biotechnology of Perennial Fruit Crops. University Press, Cambridge. pp. 57-76. 